\title{
Bioactive Compounds Isolated from Lignin of Empty Bunch Palm Fiber and Their Effects on in Vitro Rumen Fermentation
}

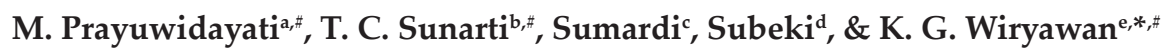 \\ aStudy Program of Nutrition and Feed Science, Faculty of Animal Science, Graduate School, \\ Bogor Agricultural University \\ ${ }^{b}$ Faculty of Agricultural Industry Technology, Bogor Agricultural University \\ cFaculty of Math and Natural Science, University of Lampung \\ dFaculty of Agriculture, University of Lampung \\ Jalan Prof. Dr. Sumantri Brojonegoro No. 1, Bandar Lampung, 35145, Indonesia \\ eFaculty of Animal Science, Bogor Agricultural University

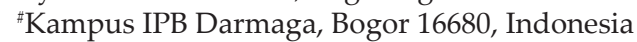 \\ (Received 30-06-2015; Reviewed 04-08-2015; Accepted 13-10-2015)
}

\begin{abstract}
The objective of this experiment was to study the effects of bioactive compounds isolated from purified lignin formacell (PLF) of empty bunch palm fiber as natural antimicrobes and their effects on in vitro rumen fermentation. The first experiment was inhibition test of 11 bioactive compounds isolated from PLF, using disc diffusion method against the growth of Escherichia coli, Salmonella typhimurium, and Staphylococcus aureus. Four of the most potential bioactive compounds were then used in the second experiment, which was an in vitro test using fresh rumen liquid of Ongole grade beef cattle, to study their effects on rumen fermentation. Six treatments with 3 replications were applied in a completely randomized block (CRB) design. The treatments were $R 0=0.5 \mathrm{~g}$ basal diet; $\mathrm{R} 1=\mathrm{R} 0+0.3 \mathrm{mg}$ Rumensin $^{\oplus ;}$ R2= R0 + $0.3 \mathrm{mg}$ syringaldehyde; $\mathrm{R} 3=\mathrm{R} 0$ + $0.3 \mathrm{mg}$ p-hydroxybenzoic acid; R4= R0 + $0.3 \mathrm{mg}$ m-hydroxybenzoic acid; and R5= R0 + $0.3 \mathrm{mg}$ oxybenzene. Isolate fraction of CC-2 (syringaldehyde), CC-3 (m-hydroxybenzoic acid), VLC-5 (oxybenzene), and VLC-9 (p-hydroxybenzoic acid) exhibited antimicrobes activity against all tested bacteria. Other isolated fractions exhibited antimicrobes activity only against 1 or 2 tested bacteria. The use of syringaldehyde, p-hydroxybenzoic acid, m-hydroxybenzoic acid, and oxybenzene improved ammonia concentration, microbial protein synthesis, and nutrients digestibility. Bioactive compounds had no effect on rumen $\mathrm{pH}$ but reduced total VFA concentration as well as the estimate of methane production.
\end{abstract}

Key words: bioactive compounds, natural antimicrobes, rumen fermentation

\section{ABSTRAK}

Penelitian bertujuan mempelajari pengaruh penggunaan senyawa bioaktif yang diperoleh dari lignin tandan buah kelapa sawit sebagai antimikrob dan pengaruhnya pada fermentasi rumen secara in vitro. Percobaan pertama adalah uji zona hambat 11 senyawa bioaktif menggunakan metode cakram pada bakteri Escherichia coli, Salmonella typhimurium, dan Staphylococcus aureus. Empat senyawa bioaktif paling baik diuji lebih lanjut dalam percobaan kedua, yaitu fermentasi in vitro menggunakan cairan rumen sapi peranakan Ongole, untuk mengamati pengaruhnya pada fermentasi rumen secara in vitro. Percobaan menggunakan rancangan acak kelompok lengkap dengan 6 perlakuan dan 3 ulangan. Perlakuan adalah $\mathrm{R} 0=0,5 \mathrm{~g}$ ransum basal; $\mathrm{R} 1=\mathrm{R} 0+0,3 \mathrm{mg}$ Rumensin ${ }^{\oplus} ; \mathrm{R} 2=\mathrm{R} 0+0,3 \mathrm{mg}$ siringaldehida; $R 3=R 0+0,3 \mathrm{mg}$ asam p-hidroksibenzoat; $\mathrm{R} 4=\mathrm{R} 0+0,3 \mathrm{mg}$ asam m-hidroksibenzoat; dan $\mathrm{R} 5=\mathrm{R} 0+0,3$ mg oksibenzena. Fraksi isolat CC-2 (siringaldehida), CC-3 (asam m-Hidroksibenzoat), VLC-5 (oksibenzena), dan VLC-9 (asam p-hidroksibenzoat) memperlihatkan aktivitas antimikrob pada ketiga bakteri patogen yang diuji. Isolat lainnya memperlihatkan aktivitas antimikrob pada 1 atau 2 saja dari bakteri patogen yang diuji. Penggunaan siringaldehida, asam p-hidroksibenzoat, asam m-hidroksibenzoat, dan oksibenzena meningkatkan konsentrasi ammonia, sintesis protein mikrob, dan kecernaan zat-zat makanan. Penggunaan senyawaan tersebut tidak mempengaruhi $\mathrm{pH}$ rumen, tetapi menurunkan konsentrasi VFA dan nilai estimasi produksi gas metan.

Kata kunci: senyawa bioaktif, antimikrob alami, fermentasi rumen 


\section{INTRODUCTION}

The use of antibiotics is continuously improved in animal production, especially for prevention of bacterial infection and growth promotion. However, antibiotics must be used judiciously because it could lead to the emergence and spread of resistant microorganisms and also creation of antibiotic-resistant disease in animal (Houser et al., 2008; Johnson et al., 2007). The increasing incidence of antibiotic-resistant pathogens has drawn the attention of scientific communities towards studies on the potential antimicrobial activity of plant-derived substances (Savoia, 2012; Fitrial et al., 2008) and potential use of probiotics for improving animal performance (Hamida et al., 2015). Therefore, there is a need to explore intensively the potential use of plant derived antimicrobes for controlling the gastrointestinal pathogenic microbes in animals.

Rochfort et al. (2008) in their review explored the potential use of medicinal properties of plants to enhance animal health in general and that of ruminants in particular. Active areas of research for plant bioactive include foam production/bloat control and methane production. The majority of plant-derived substances tested specifically for ruminants are tested in order to assess the effect on rumen ecosystem, safety aspect of rumen flora, and attempts to reduce the gram positive bacteria that may be associated with less desirable gut metabolisms. Antimicrobial effect of plant bioactives is most pronounced against gram positive bacteria, almost similar to the action of ionophores.

Salmonella has been widely reported as one of frequently found pathogenic bacteria in cattle (Hollinger et al., 1998). These pathogenic bacteria could be found in the rumen and feces samples of infected cattle. Salmonella could enter the rumen most probably through consumption of contaminated feed. High volatile fatty acid concentrations (VFA) in the rumen may inhibit the growth of Salmonella, in contrary when the cattle in starvation period the growth of Salmonella may start to increase because of low VFA concentration. Currently, the use of probiotics and antimicrobes are intensively explored to control the pathogenic bacteria in feedlot cattle and neonatal calf. Probiotics are used to reduce the use of antibiotics in neonatal and stressed calf, enhance milk production, prevent ruminal acidosis, and to rapidly establish stable microbiota in neonatal calves (Krehbiel et al., 2003).

Plant antimicrobes are phytochemicals, which are broadly grouped into phenolic compounds, terpenoids, essential oils, alkaloids, and polypeptides. Phenolic compounds are involved in plant growth to provide resistance from pathogens and predator. The structure of phenolics consists of an aromatic ring carrying one (phenol) or more hydroxyl (polyphenol) moieties. Several classes can be distinguished according to the number of phenol rings and to the structural elements that join these rings (Khadem \& Marles, 2010).

Interest in the antimicrobial properties of phenolic compounds is strengthened by the finding that they affect the behavior of pathogenic bacteria and their use as natural additive in food industry (Nazzaro et al., 2009).
The antimicrobial activity of phenolic compounds and flavonoids were reported by Erdemoglu et al. (2007) and Xia et al. (2011). Other study (Nohynek et al., 2006) demonstrated that phenolic extracts inhibit the growth of pathogenic bacteria of human gastrointestinal tract. The mechanisms responsible for phenolic compounds to control pathogenic bacteria in gastrointestinal tract are still needs further studies. However, several mechanisms are proposed; include absorption and disruption of microbial membranes, interaction with enzymes, and metal ion deprivation (Fattouch et al., 2007; Xia et al., 2011). Therefore, there are lots of possibilities of exploring the use of phenolic compounds as natural antimicrobial agents in gastrointestinal tract of animals.

It has long been demonstrated that lignin is one of the major source of polyphenolic compounds available from natural biomass (Yang et al., 2007). When the lignin portion of plant biomass is hydrolyzed, various phenolic acids are released (Lee et al., 2012). Purified lignin formacell of empty bunch palm fiber (EBPF) contained significant amount of phenolic compounds. Since phenolic acids from different sources of lignin have specific effects on certain microbes, there is a need to study the antimicrobial effects of phenolic compounds isolated from certain sources of lignin. Objective of this experiment was to study the use of active compounds isolated from lignin of empty bunch palm fiber as natural antimicrobes and their effects on in vitro rumen fermentation. The bioactive compounds used were Syringaldehyde, p-Hydroxybenzoic acid, m-Hydroxybenzoic acid, and Oxybenzene.

\section{MATERIALS AND METHODS}

\section{Lignin Fractionation}

Empty bunch palm fiber was collected from local palm oil industry in Rejosari, Lampung Province, Indonesia. Lignin Formacell (LF) was isolated from ground EBPF (30-40 mesh) using pulping formacell method (Lehnen et al., 2005). LF was then further purified to obtain Purified Lignin Formacell (PLF). PLF was then further analyzed using gas chromatography mass spectroscopy (GCMS) to describe its monomers.

Two methods were then applied to obtain the bioactive compounds candidate from PLF of EBPF. The two methods were used to obtain the most bioactive compounds, since certain method only effective for some type of bioactive compounds. Method 1 (Lundquist, 1973; Faustino et al., 2010) was fractionation of PLF, followed by extraction, and then separation of active compounds using column chromatography. In fractionation process, $4 \mathrm{~g}$ PLF was diluted in $50 \mathrm{~mL}$ "white liquor" $\left(\mathrm{NaOH} 1.38 \mathrm{M}\right.$ and $\left.\mathrm{Na}_{2} \mathrm{~S} 0.25 \mathrm{M}\right)$ then heated at $170{ }^{\circ} \mathrm{C}$ for $4 \mathrm{~h}$. After reaching the room temperature, the solution was then added with $200 \mathrm{~mL}$ of dioxan and $\mathrm{HCl} 2$ $\mathrm{M}$ until $\mathrm{pH}$ 2-3 was reached. Extraction process was conducted in 3 steps, which consisted of: (a) using 200 $\mathrm{mL}$ of $\mathrm{CHCl}_{3}$; (b) using $100 \mathrm{~mL}$ of dioxan- $\mathrm{CHCl}_{3}$ (1:1); and (c) using $2 \times 50 \mathrm{~mL}$ of $\mathrm{CHCl}_{3}$. Organic layer materials were obtained from this extraction process. The organic layer materials were then decanted, the dioxan- 
chloroform was removed by vacuum evaporator, and then crude extract of active compounds were subjected to column chromatography (CC) using $15 \mathrm{~g}$ of silica and chloroform/ethyl acetate 1:10 as eluent to separate the active compounds. Crystal active compounds obtained were then analyzed using thin layer chromatography (TLC) to classify the active compounds with the same retention factor (Rf) value. All active compounds obtained were then tested against the growth of Escherichia coli, Salmonella typhimurium, and Staphylococcus aureus.

Method 2 (Faustino et al., 2010; Sticher, 2008 with slightly modification) was fractionation of PLF, followed by extraction, and then separation of active compounds using vacuum liquid chromatography. Before fractionation, PLF was macerated using methanol for 1-3 d. Methanol soluble fraction was then separated from methanol insoluble fraction by sieving. A volume of 4 $\mathrm{N} \mathrm{HCl}(100 \mathrm{~mL})$ was added under stirring liquid phase (1000 mL) giving rise to a solution of $\mathrm{pH} 6$. This solution was then centrifuged at 4,500 rpm for 7 min or kept overnight, until the solid fraction and supernatant was separated. Supernatant was then decanted and extracted with ethyl acetate using ethyl acetate solution with volume ratio of 1:3 (v/v) in a single extraction step. The ethyl acetate was removed by vacuum evaporation and the crude extract was subjected to vacuum liquid chromatography (VLC) using chloroform/methanol as eluent to separate the active compounds candidate. The modification was the ratio of eluent methanol:chloroform; in this experiment non polar to polar ratio was used at 0:100 (VLC-1), 10:90 (VLC-2), 20:80 (VLC-3), 30:70 (VLC4), 40:60 (VLC-5), 50:50 (VLC-6), 60:40 (VLC-7), 70:30 (VLC-8), 100:0 (VLC-9). Crystal active compounds were obtained which were then analyzed by using thin layer chromatography (TLC) to classify the active compounds with the same retention factor (Rf) value. All active compound candidates were then tested by using inhibition test method against the growth of E. coli, S. typhimurium, and S. aureus.

\section{Antimicrobial Activity of Selected Isolates}

This experiment was inhibition zone test of all bioactive compound candidates isolated from PLF of EBPF. Inhibition zone test was conducted by using disc diffusion method (Satirapathkul \& Leela, 2011) and the tested pathogenic bacteria comprised of E. coli, S. typhimurium, and $S$. aureus. The bacteria were maintained by subculturing periodically on nutrient agar and were preserved at $4^{\circ} \mathrm{C}$ prior to usage.

Culture media. The nutrient agar was composed of 20 $\mathrm{g}$ agar, $5 \mathrm{~g}$ peptone, $1.5 \mathrm{~g}$ yeast extract, $1.5 \mathrm{~g}$ beef extract and $5 \mathrm{~g} \mathrm{NaCl}$, diluted in $1000 \mathrm{~mL}$ distilled water. The mixture of nutrient was then boiled and its $\mathrm{pH}$ was adjusted to a range of 6.4-6.8. The mixture of nutrient was then autoclaved (at temperature of $121^{\circ} \mathrm{C}$ and pressure of 15 psi) for $20 \mathrm{~min}$. Nutrient mixture was then poured into sterilized petri plates for culture media. All of the tested pathogenic bacteria were then grown overnight (at temperature of $37^{\circ} \mathrm{C}$ and rotation of $120 \mathrm{rpm}$ ) in nutrient broth, and part of this broth was then used for seeding the bacteria in culture media.

Antimicrobial assay. Discs of filter paper were impregnated with $0.3 \mathrm{mg}$ of each diluted crystal of bioactive compound. The discs were then placed on the top part of the seeded media plate of the tested bacteria. The plates were then incubated at $37^{\circ} \mathrm{C}$ for $24 \mathrm{~h}$. The diameters of the clearing zone in each plate was then recorded. As positive controls, the discs of the standard antibiotics; Rumensin ${ }^{\circledR}$ (Elanco) (0.3 mg per disc) were used in this experiment. Diameter of the zone of inhibition in each disc was then assumed as a measure of antibacterial activity of the tested bioactive compounds. The diameters of the inhibition zones by the bioactive compounds were then compared with that of Rumensin ${ }^{\circledR}$ discs. Each of the antimicrobial assays was conducted in duplicate.

\section{In Vitro Rumen Fermentation}

Selected potential bioactive compounds that exhibited higher inhibition activity from previous experiment were then further studied in in vitro rumen fermentation. This in vitro experiment was conducted in a completely randomized block design with 6 treatments in 3 blocks, with rumen fluid from different cattle as a block. The treatments were $\mathrm{R}_{0}=0.5 \mathrm{~g}$ of basal diet (contained $66.7 \%$ TDN and $14.7 \%$ crude protein); $R_{1}=R_{0}+0.3 \mathrm{mg}$ of Rumensin ${ }^{\circledR} ; R_{2}=R_{0}+0.3 \mathrm{mg}$ of Syringaldehyde; $R_{3}=$ $\mathrm{R}_{0}+0.3 \mathrm{mg}$ of p-Hydroxybenzoic acid; and $\mathrm{R}_{4}=\mathrm{R}_{0}+0.3$ $\mathrm{mg}$ of $\mathrm{m}$-Hydroxybenzoic acid; and $\mathrm{R}_{5}=\mathrm{R}_{0}+0.3 \mathrm{mg}$ of Oxybenzene. Ingredient composition of the basal diet is presented in Table 1.

Rumen contents were collected just about $3 \mathrm{~h}$ after morning feeding from $400 \mathrm{~kg}$ ruminally fistulated Ongole grade beef cattle in LIPI Cibinong Indonesia, which were maintained on basal diet composed of $40 \%$ forage and $60 \%$ concentrate. The rumen fluid was filtered through a double layer cheese cloth which was then used as inoculum. The substrate for the fermenta-

Table 1. Ingredient composition and calculated nutritional content of basal diet

\begin{tabular}{lrrrrr}
\hline & \multirow{2}{*}{$\begin{array}{c}\text { Dry } \\
\text { Ingredients }\end{array}$} & \multicolumn{5}{c}{ Nutrient contents (\% DM) } \\
\cline { 5 - 6 } & $(\%)$ & TDN & $\begin{array}{c}\text { Crude } \\
\text { protein }\end{array}$ & Ca & $\mathrm{P}$ \\
\hline Forage & & & & & \\
$\quad \begin{array}{l}\text { Pennisetum } \\
\text { purpureum }\end{array}$ & 25.0 & 15.43 & 2.88 & 0.17 & 0.06 \\
$\quad$ Gliricidia sepium & 15.0 & 11.25 & 4.01 & 0.02 & 0.02 \\
Concentrate & & & & & \\
$\quad$ Cassava waste & 21.1 & 13.34 & 0.91 & 0.04 & 0.01 \\
Rice bran & 11.1 & 7.27 & 1.42 & 0.01 & 0.19 \\
Corn meal & 9.0 & 6.84 & 0.79 & 0.01 & 0.02 \\
$\quad$ Tofu waste & 9.3 & 6.88 & 2.48 & 0.02 & 0.00 \\
Coconut oil meal & 7.5 & 5.65 & 2.22 & 0.01 & 0.01 \\
$\quad$ Bone meal & 1.0 & 0.00 & 0.00 & 0.32 & 0.11 \\
$\quad \begin{array}{l}\text { Vitamin and } \\
\text { mineral mix }\end{array}$ & 1.0 & 0.00 & 0.00 & 0.05 & 0.02 \\
Total & & & & & \\
\hline
\end{tabular}


tion was a basal diet composed of $40 \%$ forage and $60 \%$ concentrate, containing $66.5 \% \mathrm{TDN}$ and $14.7 \%$ crude protein $(\mathrm{CP})$.

In vitro rumen fermentation was conducted according to the method of Tilley \& Terry (1963). An amount of $500 \mathrm{mg}$ of substrate and $40 \mathrm{~mL}$ of McDougal buffer solution were added into individual fermentation tube, and then $10 \mathrm{~mL}$ of strained rumen fluid was inoculated to the medium. McDougal buffer solution contained $\mathrm{NaHCO}_{3} 58.8 \mathrm{~g}, \mathrm{Na}_{2} \mathrm{HPO}_{4} .7 \mathrm{H}_{2} \mathrm{O} 42 \mathrm{~g}, \mathrm{KCl} 3.42 \mathrm{~g}, \mathrm{NaCl}$ $2.82 \mathrm{~g}, \mathrm{MgSO}_{4} .7 \mathrm{H}_{2} \mathrm{O} 0.72 \mathrm{~g}, \mathrm{CaCl}_{2} 0.24 \mathrm{~g}$, and $\mathrm{H}_{2} \mathrm{O}$ in 6 $\mathrm{L}$ solution. The fermentation medium was stirred and flushed with carbon dioxide to establish anaerobic condition and the tubes were then sealed with a rubber cork fitted with the gas release valve. Fermentation tubes were then incubated in a shaker water-bath at $39^{\circ} \mathrm{C}$ for $24 \mathrm{~h}$.

Individual VFA of the rumen fluid aliquots were analyzed by using gas chromatography (Filípek \& Dvořák, 2009). About $1 \mathrm{~mL}$ of rumen fluid sample was added with $200 \mu \mathrm{L}$ of metaphosphoric acid (25\%) and formic acid (3:1) mixture. After $10 \mathrm{~min}$ of centrifugation (12000 rpm), the clear supernatant was x10 diluted in water, then $1 \mu \mathrm{L}$ of it was injected in a 6820 GC System gas chromatograph, Agilent Technologies. A FFAP capillary column was used, $30 \mathrm{~m}$ x $250 \mu \mathrm{m}$ x $0.25 \mu \mathrm{m}$ (Quadrex Corporation). Nitrogen was used as a gas carrier, flow $1.0 \mathrm{~mL} / \mathrm{min}$; temperature programme: detector - FID $\left(300^{\circ} \mathrm{C}\right)$; injector $\left(250^{\circ} \mathrm{C}\right)$. Ammonia concentration of the rumen fluid aliquots was analyzed using the micro diffusion method (Conway, 1962). Rumen microbial protein synthesis was determined as acid prepicitable nitrogen, described by Makkar et al. (1982).

\section{Data Analysis}

All data collected were subjected to analysis of variance (ANOVA) followed by least significant difference (LSD) test. Computation was performed by using SPSS 13.0 for windows evaluation system and Microsoft Excel 2010.

\section{RESULTS AND DISCUSSION}

Results of GCMS analysis revealed that purified lignin formacell of empty bunch of palm fiber contained 19 bioactive phenolic compounds. Percentage of these detected bioactive compounds ranged from the lowest 2,3-Dimethylphenol $(0.16 \%)$ to the highest Syringol (23.75\%). List of phenolic compounds detected in PLF of EBPF are presented in Table 2. Among the 19 detected bioactive compounds, syringol, p-hydroxybenzoic acid, guaiacol, acetosyringone, and 2-methoxy-4-methylphenol were 5 among the phenolic compounds detected that had higher percentage in the PLF (>9\% of PLF).

Results of two methods of fractionation, extraction, and separation processes revealed that purified lignin formacell (PLF) of empty bunch of palm fiber (EBPF) contained 11 isolate fractions. Four isolate fractions were obtained from Method 1 (column chromatography, CC) and 7 isolate fractions were obtained from Method 2 (vacuum liquid chromatography, VLC). The isolates fractions were differentiated based on their $\mathrm{Rf}$ value from thin layer chromatography (TLC) test. The isolate fractions isolated from PLF of EBPF and it retention factor (Rf) value are presented in Table 3.

\section{Antimicrobial Activity of Selected Isolates}

Table 4 indicated that 4 isolate fractions, which was fraction CC-2, fraction CC-3, fraction VLC-5, and

Table 2. List of phenolic compounds detected in purified lignin formacell (PLF) of empty bunch palm fiber (EBPF)

\begin{tabular}{lrcc}
\hline \multicolumn{1}{c}{ Phenolic compounds ${ }^{*}$} & $\%$ & Formula & $\begin{array}{c}\text { Molecular } \\
\text { weight }\end{array}$ \\
\hline Syringol & 23.75 & $\mathrm{C}_{8} \mathrm{H}_{10} \mathrm{O}_{3}$ & 154 \\
p-Hydroxybenzoic acid & 14.19 & $\mathrm{C}_{7} \mathrm{H}_{6} \mathrm{O}_{3}$ & 138 \\
Guaiacol & 11.21 & $\mathrm{C}_{7} \mathrm{H}_{8} \mathrm{O}_{2}$ & 124 \\
Acetosyringone & 9.79 & $\mathrm{C}_{10} \mathrm{H}_{12} \mathrm{O}_{4}$ & 196 \\
2-Methoxy-4-methylphenol & 9.53 & $\mathrm{C}_{8} \mathrm{H}_{10} \mathrm{O}_{2}$ & 138 \\
3-Methoxy-pyrocatechol & 8.33 & $\mathrm{C}_{7} \mathrm{H}_{8} \mathrm{O}_{3}$ & 140 \\
3-Methoxyacetophenone & 6.46 & $\mathrm{C}_{9} \mathrm{H}_{10} \mathrm{O}_{2}$ & 150 \\
Monophenol & 5.15 & $\mathrm{C}_{6} \mathrm{H}_{6} \mathrm{O}$ & 94 \\
Syringaldehyde & 2.63 & $\mathrm{C}_{9} \mathrm{H}_{10} \mathrm{O}_{4}$ & 182 \\
Acetovanillone & 2.09 & $\mathrm{C}_{9} \mathrm{H}_{10} \mathrm{O}_{3}$ & 166 \\
Vanillin & 1.90 & $\mathrm{C}_{8} \mathrm{H}_{8} \mathrm{O}_{3}$ & 152 \\
Eugenol & 1.65 & $\mathrm{C}_{10} \mathrm{H}_{12} \mathrm{O}_{2}$ & 164 \\
o-Cresol & 0.95 & $\mathrm{C}_{7} \mathrm{H}_{8} \mathrm{O}$ & 108 \\
3-Methoxy-2,5,6-trimethylphe- & 0.57 & $\mathrm{C}_{10} \mathrm{H}_{14} \mathrm{O}_{2}$ & 166 \\
nol & & $\mathrm{C}_{8} \mathrm{H}_{10} \mathrm{O}_{2}$ & 138 \\
2-Methoxy-4-methylphenol & 0.54 & $\mathrm{C}_{10} \mathrm{H}_{12} \mathrm{O}_{3}$ & 180 \\
Coniferyl alcohol & 0.45 & $\mathrm{C}_{8} \mathrm{H}_{10} \mathrm{O}$ & 122 \\
p-Ethylphenol & 0.35 & $\mathrm{C}_{9} \mathrm{H}_{10} \mathrm{O}_{4}$ & 182 \\
Homovanillic acid & 0.31 & $\mathrm{C}_{8} \mathrm{H}_{10} \mathrm{O}$ & 122 \\
2,3-Dimethylphenol & 0.16 & & \\
\hline
\end{tabular}

Note: ")Analyzed using Shimadzu GCMS-QP 2010.

Table 3. Phenolic compounds of purified lignin formacell (PLF)

\begin{tabular}{lccc}
\hline \multirow{2}{*}{$\begin{array}{l}\text { Fractionation } \\
\text { results }\end{array}$} & \multicolumn{3}{c}{${ }^{* * *} \mathrm{TLC}$ Test } \\
\cline { 2 - 4 } & Rf value & Eluent & Ratio eluent \\
\hline Method 1* & & & \\
Fraction of CC-1 & 0.72 & EtOAc $: \mathrm{CHCl}_{3}$ & $10: 01$ \\
Fraction of CC-2 & 0.66 & EtOAc $: \mathrm{CHCl}_{3}$ & $10: 01$ \\
Fraction of CC-3 & 0.83 & EtOAc $: \mathrm{CHCl}_{3}$ & $10: 01$ \\
Fraction of CC-4 & 0.55 & Dioxan : air & $1: 01$ \\
Method 2 & & & \\
Fraction of VLC-2 & 0.38 & $\mathrm{MeOH}: \mathrm{CHCl}_{3}$ & $80: 20: 00$ \\
Fraction of VLC-3 & 0.69 & EtOAc $: \mathrm{CHCl}_{3}$ & $10: 01$ \\
Fraction of VLC-4 & 0.79 & EtOAc: $\mathrm{CHCl}_{3}$ & $10: 01$ \\
Fraction of VLC-5 & 0.38 & $\mathrm{MeOH}: \mathrm{CHCl}_{3}$ & 0.479 \\
Fraction of VLC-6 & 0.45 & $\mathrm{MeOH}: \mathrm{CHCl}_{3}$ & 0.479 \\
Fraction of VLC-8 & 0.50 & $\mathrm{MeOH}: \mathrm{CHCl}_{3}$ & 0.479 \\
Fraction of VLC-9 & 0.71 & $\mathrm{MeOH}: \mathrm{CHCl}_{3}$ & 0.479 \\
\hline
\end{tabular}

Note: ${ }^{*} \mathrm{CC}=$ Column Chromatography; ${ }^{* *}$ VLC $=$ Vacuum Liquid Chromatography: ${ }^{* *} \mathrm{TLC}=$ Thin Layer Chromatography; $\mathrm{Rf}=$ retention factor. 
fraction VLC-9 exhibited antimicrobial activity against all tested bacteria (E. coli, S. typhimurium, and S. aureus). Other isolated fractions exhibited antimicrobial activity against only 1 or 2 tested bacteria. Level of antimicrobial activity of all isolate fractions obtained was still lower compare with that of Rumensin ${ }^{\circledR}$ (one of commercial antibiotic product).

Pan et al. (2009) classified the level of antimicrobial activity based on diameter of inhibition zone as follow: inhibition zone $<3 \mathrm{~mm}$ was considered low, 3-6 mm was medium, and $>6 \mathrm{~mm}$ was high. Based on this classification, fraction CC-1 only had high activity against $S$. aureus; fraction CC-2 had high activity against all tested pathogenic bacteria; fraction CC-3 had medium activity against all tested pathogenic bacteria; fraction CC-4 and VLC-6 had medium activity against $S$. aureus; fraction VLC-2, and VLC-8 had high activity against S. aureus; fraction VLC-5 had high activity against $S$. aureus, medium activity against $S$. typhimurium, and low activity against E. coli; and fraction VLC-9 has high activity against $S$. typhimurium and $S$. aureus. No inhibition zone was observed for fraction VLC-3 and VLC-4.

Table 4 also showed that more inhibition zone was demonstrated by the isolate fractions against the $S$. aureus, compared with that of E. coli and S. typhimurium. This result revealed that $S$. aureus was more susceptible to all isolated fractions compared to E. coli and S. typhimurium. S. aureus is a gram positive bacteria, which is more susceptible to antimicrobial agent compared with gram negative bacteria (Gonzales et al., 2006). The outer part of cell membrane of gram positive bacteria contains small amounts of lipopolysaccharides that is not sufficient to protect the cell from penetration by antimicrobes.

Four of most potential isolate fractions among the 11 isolate fractions obtained were then further analyzed by using gas chromatography mass spectroscopy (GCMS) to describe its monomers. Result of the GCMS analysis of the most potential bioactive compounds is presented in Table 5. Bioactive compounds obtained from the isolate fractions (crystal) were Oxybenzene (VLC-5 fraction), p-Hydroxybenzoic acid (VLC-9 fraction), Syringaldehyde (CC-2 fraction), and $\mathrm{m}$ Hydroxybenzoic acid (CC-3 fraction). It is known that p-Hydroxybenzoic acid and m-Hydroxybenzoic acid is polyphenol compounds of non flavonoid sub-group of benzoic acids.

\section{In Vitro Rumen Fermentation}

Effects of treatment on ruminal metabolism variables of in vitro fermentation are presented in Table 6. The used of Rumensin ${ }^{\circledR}$, syringaldehyde, p-hydroxybenzoic acid, m-hydroxybenzoic, and oxybenzene did not change the rumen $\mathrm{pH}$, which were stable in the range of 6.60-6.70, which were considered normal $\mathrm{pH}$ for optimal rumen fermentation. This result indicates that the use of these bioactive compounds in this experiment did not have adverse effects on rumen metabolism. Rochfort et al. (2008) stated that the plant-derived substances should not have deleterious effect on ruminal flora, since ruminants drive much of their nutrition through bacterial gut fermentation. The same result is reported by Ozturk et al. (2010) that the rumen $\mathrm{pH}$ remains unchanged (6.8) when propolis ethanolic extract is given as antimicrobial product in rumen microbial fermentation using rumen simulation technique (Rusitec).

Table 6 also shows that ammonia concentration of fermentation medium significantly increased $(\mathrm{P}<0.05)$ by addition of Rumensin ${ }^{\circledR}$, syringaldehyde, p-hydroxybenzoic acid, m-hydroxybenzoic, and oxybenzene. However, an ammonia concentrations of Rumensin ${ }^{\circledR}$ treatment was still higher than that of syringaldehyde, p-hydroxybenzoic acid, m-hydroxybenzoic, and oxybenzene treatment. These results indicate that bioactive compounds have positive effect on ammonia supply

Table 4. Diameter of inhibition zone against E. coli, S. typhimurium, and S. aureus obtained from inhibition test of isolate fractions

\begin{tabular}{|c|c|c|c|c|c|c|}
\hline \multirow{2}{*}{ Compounds } & \multicolumn{2}{|c|}{ E coli } & \multicolumn{2}{|c|}{ S. typhimurium } & \multicolumn{2}{|c|}{ S. aureus } \\
\hline & Treatment & Rumensin $\AA$ & Treatment & Rumensin ${ }^{\circledR}$ & Treatment & Rumensin ${ }^{\circledR}$ \\
\hline & \multicolumn{6}{|c|}{--- } \\
\hline \multicolumn{7}{|l|}{ Method $1^{*}$} \\
\hline Fraction of CC-1 & - & $14.00 \pm 0.09$ & $3.63 \pm 0.03$ & $14.05 \pm 0.13$ & $8.56 \pm 0.39$ & $14.50 \pm 0.35$ \\
\hline Fraction of CC-2 & $8.28 \pm 0.34$ & $13.93 \pm 0.20$ & $9.17 \pm 0.06$ & $14.18 \pm 0.12$ & $10.23 \pm 0.80$ & $16.18 \pm 0.00$ \\
\hline Fraction of CC-3 & $5.52 \pm 0.20$ & $13.08 \pm 0.03$ & $4.42 \pm 0.13$ & $11.05 \pm 0.28$ & $5.48 \pm 0.36$ & $13.60 \pm 0.35$ \\
\hline Fraction of CC-4 & - & $12.88 \pm 0.10$ & - & $11.22 \pm 0.03$ & $4.92 \pm 0.11$ & $12.45 \pm 0.97$ \\
\hline \multicolumn{7}{|l|}{ Method $2^{* *}$} \\
\hline Fraction of VLC-2 & - & $14.25 \pm 0.26$ & - & $15.58 \pm 0.23$ & $9.10 \pm 0.20$ & $15.88 \pm 0.81$ \\
\hline Fraction of VLC-3 & - & $13.17 \pm 0.06$ & - & $12.38 \pm 0.20$ & - & $12.58 \pm 0.36$ \\
\hline Fraction of VLC-4 & - & $12.60 \pm 0.09$ & - & $11.73 \pm 0.24$ & - & $10.70 \pm 0.31$ \\
\hline Fraction of VLC-5 & $2.38 \pm 0.23$ & $13.63 \pm 0.08$ & $3.13 \pm 0.03$ & $13.02 \pm 0.06$ & $13.33 \pm 0.65$ & $13.37 \pm 0.08$ \\
\hline Fraction of VLC-6 & - & $11.82 \pm 0.03$ & - & $13.27 \pm 0.14$ & $4.46 \pm 0.16$ & $12.80 \pm 0.23$ \\
\hline Fraction of VLC-8 & - & $13.52 \pm 0.38$ & - & $12.63 \pm 0.29$ & $9.67 \pm 0.19$ & $14.31 \pm 0.33$ \\
\hline Fraction of VLC-9 & $5.47 \pm 0.13$ & $14.10 \pm 0.05$ & $7.42 \pm 0.14$ & $13.18 \pm 0.15$ & $10.75 \pm 0.00$ & $15.10 \pm 0.00$ \\
\hline
\end{tabular}

Note: ${ }^{*} \mathrm{CC}=$ Column Chromatography; ${ }^{* *} \mathrm{VLC}=$ Vacuum Liquid Chromatography. 
Table 5. Description of the most potential isolate fractions obtained from purified lignin formacell (PLF) of empty bunch palm fiber (EBPF)

\begin{tabular}{|c|c|c|c|c|}
\hline Crystal & Bioactive compounds*) & Formula & Molecular weight (Da) & Structure \\
\hline VLC-5 fraction & Oxybenzene & $\mathrm{C}_{6} \mathrm{H}_{6} \mathrm{O}$ & 94.111 & \\
\hline VLC-9 fraction & p-Hydroxybenzoic acid & $\mathrm{C}_{7} \mathrm{H}_{6} \mathrm{O}_{3}$ & 138.121 & \\
\hline CC-2 fraction & Syringaldehyde & $\mathrm{C}_{9} \mathrm{H}_{10} \mathrm{O}_{4}$ & 182.173 & \\
\hline CC-3 fraction & m-Hydroxybenzoic acid & $\mathrm{C}_{7} \mathrm{H}_{6} \mathrm{O}_{3}$ & 138.121 & \\
\hline
\end{tabular}

Note: ${ }^{*}$ Analyzed using Shimadzu GCMS-QP 2010.

Table 6. Ruminal metabolism variables at different ration treatments

\begin{tabular}{|c|c|c|c|c|c|c|}
\hline \multirow{2}{*}{ Variables } & \multicolumn{6}{|c|}{ Treatmeants } \\
\hline & R0 & $\mathrm{R} 1$ & $\mathrm{R} 2$ & $\mathrm{R} 3$ & $\mathrm{R} 4$ & R5 \\
\hline $\mathrm{pH}$ & $6.63 \pm 0.12$ & $6.60 \pm 0.00$ & $6.67 \pm 0.06$ & $6.70 \pm 0.00$ & $6.67 \pm 0.06$ & $6.63 \pm 0.06$ \\
\hline $\mathrm{NH}_{3}, \mathrm{mM}$ & $5.35 \pm 0.56^{c}$ & $10.01 \pm 4.67^{a}$ & $7.46 \pm 3.30^{\mathrm{b}}$ & $7.40 \pm 2.60^{\mathrm{b}}$ & $7.64 \pm 4.32^{\mathrm{b}}$ & $7.83 \pm 2.79^{\mathrm{b}}$ \\
\hline Total VFA, mM & $90.30 \pm 5.45^{\mathrm{a}}$ & $84.23 \pm 2.91^{\mathrm{ab}}$ & $84.93 \pm 6.39^{\mathrm{ab}}$ & $75.84 \pm 12.89^{c}$ & $74.86 \pm 5.87^{c}$ & $83.78 \pm 3.83^{b}$ \\
\hline - Acetic acid (C2), mM & $62.32 \pm 4.68$ & $56.68 \pm 3.56$ & $58.49 \pm 4.63$ & $52.70 \pm 10.20$ & $49.95 \pm 5.18$ & $56.25 \pm 2.48$ \\
\hline - Propionic acid (C3), mM & $19.28 \pm 1.54$ & $18.57 \pm 0.48$ & $17.86 \pm 1.11$ & $15.88 \pm 2.02$ & $16.10 \pm 2.21$ & $18.96 \pm 1.52$ \\
\hline - Iso-butyric acid, mM & $0.55 \pm 0.10$ & $0.43 \pm 0.01$ & $0.43 \pm 0.04$ & $0.85 \pm 0.27$ & $1.34 \pm 0.65$ & $0.68 \pm 0.02$ \\
\hline - n-Butyric acid (C4), mM & $6.70 \pm 0.65$ & $7.01 \pm 0.30$ & $6.85 \pm 0.71$ & $5.41 \pm 0.78$ & $5.98 \pm 0.53$ & $6.61 \pm 0.22$ \\
\hline - iso-Valeric, $\mathrm{mM}$ & $0.50 \pm 0.10$ & $0.55 \pm 0.04$ & $0.52 \pm 0.07$ & $0.41 \pm 0.03$ & $0.65 \pm 0.08$ & $0.50 \pm 0.05$ \\
\hline - n-Valerate (C5), mM & $0.95 \pm 0.25$ & $0.98 \pm 0.10$ & $0.79 \pm 0.18$ & $0.60 \pm 0.09$ & $0.84 \pm 0.20$ & $0.78 \pm 0.12$ \\
\hline - Iso acid & $2.00 \pm 0.44^{\mathrm{b}}$ & $1.96 \pm 0.09^{\mathrm{b}}$ & $1.73 \pm 0.29^{\mathrm{b}}$ & $1.86 \pm 0.37^{\mathrm{b}}$ & $2.69 \pm 0.27^{a}$ & $1.96 \pm 0.15^{\mathrm{b}}$ \\
\hline - C2/C3 ratio & $3.24 \pm 0.33^{\mathrm{ab}}$ & $3.06 \pm 0.27^{\mathrm{ab}}$ & $3.28 \pm 0.18^{\mathrm{ab}}$ & $3.31 \pm 0.40^{\mathrm{a}}$ & $3.13 \pm 0.47^{\mathrm{ab}}$ & $2.98 \pm 0.20^{\mathrm{b}}$ \\
\hline - Non-Glucogenic Ratio (NGR)a) & $3.80 \pm 0.35^{\mathrm{ab}}$ & $3.67 \pm 0.25^{\mathrm{ab}}$ & $3.92 \pm 0.18^{\mathrm{a}}$ & $3.90 \pm 0.40^{\mathrm{a}}$ & $3.74 \pm 0.45^{\mathrm{ab}}$ & $3.57 \pm 0.26^{\mathrm{b}}$ \\
\hline - Estimate of methane production ${ }^{\text {b) }}$ & $25.43 \pm 2.17^{a}$ & $23.20 \pm 1.65^{\mathrm{b}}$ & $24.15 \pm 2.10^{\mathrm{ab}}$ & $21.51 \pm 4.46^{c}$ & $20.44 \pm 2.29^{c}$ & $22.74 \pm 1.01^{\mathrm{b}}$ \\
\hline Microbial protein synthesis, $\mathrm{mg} / \mathrm{mL}$ & $26.52 \pm 7.88^{\mathrm{b}}$ & $33.52 \pm 7.64^{\mathrm{a}}$ & $29.22 \pm 6.68^{\mathrm{ab}}$ & $31.41 \pm 2.16^{\mathrm{ab}}$ & $32.81 \pm 2.09^{\mathrm{a}}$ & $32.31 \pm 1.65^{\mathrm{ab}}$ \\
\hline Total gas, mL/g BO & $168.17 \pm 27.97$ & $161.10 \pm 18.88$ & $165.47 \pm 16.12$ & $166.94 \pm 36.48$ & $164.21 \pm 24.38$ & $164.86 \pm 23.47$ \\
\hline
\end{tabular}

Note: Means with different superscript at the same rows differ significantly $(\mathrm{P}<0.05)$, tested by LSD Test. R0= Basal diet; $\mathrm{R} 1=\mathrm{R} 0+\mathrm{Rumensin} \otimes 0.3 \mathrm{mg}$; $\mathrm{R} 2=\mathrm{R} 0+$ Syringaldehyde $0.3 \mathrm{mg} ; \mathrm{R} 3=\mathrm{R} 0+\mathrm{p}$-Hydroxybenzoic acid $0.3 \mathrm{mg} ; \mathrm{R} 4=\mathrm{R} 0+\mathrm{m}-\mathrm{Hydroxybenzoic}$ acid $0.3 \mathrm{mg} ; \mathrm{R} 5=\mathrm{R} 0+\mathrm{Oxybenzene} 0.3 \mathrm{mg}$. a) NGR calculated as $(\mathrm{C} 2+2 \mathrm{C} 4+\mathrm{C} 5) /(\mathrm{C} 3+\mathrm{C} 5)$ (Abrahamse et al., 2008).

${ }^{\text {b) }} \mathrm{CH}_{4}$ calculated as $0.45 \mathrm{C} 2-0.275 \mathrm{C} 3+0.40 \mathrm{C} 4$.

for rumen bacterial growth, because ammonia is well known as the preferred source of nitrogen for microbial protein synthesis in the rumen. Rumen microbial protein synthesis data confirmed this theory and revealed that addition of Syringaldehyde, p-Hydroxybenzoic acid, m-Hydroxybenzoic, and Oxybenzene slightly increased the rumen microbial protein synthesis.

Increasing rumen microbial protein synthesis is mostly followed by reducing ammonia concentration (Mwenya et al., 2005). However, since nitrogen for bacterial protein synthesis is also supplied by amino acids and peptides, in certain condition improving in rumen bacterial protein synthesis is not always followed by reducing in ammonia concentration. Rumen bacterial yield usually increases when amino acids are included in the growth medium. Result of this experiment indicates that higher rumen microbial protein synthesis in Syringaldehyde, p-Hydroxybenzoic acid, m-Hydroxybenzoic, and Oxybenzene treatment were possibly also supported by nitrogen from amino acids and peptides in medium as main products of protein digestion. Crude protein digestion data (Table 7) confirmed this situation. 
Table 7. Nutrient digestibility of ration treatments $(\%)$

\begin{tabular}{lcccccc}
\hline \multirow{2}{*}{ Nutrients digestibilities } & \multicolumn{5}{c}{ Treatments } \\
\cline { 2 - 7 } & R0 & R1 & R2 & R3 & R4 & R5 \\
\hline Dry matter digestibility & $69.67 \pm 0.94^{\mathrm{c}}$ & $71.44 \pm 2.53^{\mathrm{bc}}$ & $71.65 \pm 0.49^{\mathrm{abc}}$ & $73.75 \pm 0.89^{\mathrm{a}}$ & $71.46 \pm 3.45^{\mathrm{bc}}$ & $73.41 \pm 1.78^{\mathrm{ab}}$ \\
Organic matter digestibility & $64.25 \pm 0.82^{\mathrm{c}}$ & $66.67 \pm 3.47^{\mathrm{ab}}$ & $66.90 \pm 0.89^{\mathrm{ab}}$ & $69.31 \pm 0.60^{\mathrm{a}}$ & $66.45 \pm 4.33^{\mathrm{bc}}$ & $68.87 \pm 2.46^{\mathrm{ab}}$ \\
Crude protein digestibility & $75.44 \pm 1.47^{\mathrm{c}}$ & $80.17 \pm 2.52^{\mathrm{a}}$ & $77.33 \pm 0.16^{\mathrm{bc}}$ & $78.25 \pm 0.89^{\mathrm{ab}}$ & $77.63 \pm 2.26^{\mathrm{b}}$ & $77.63 \pm 2.71^{\mathrm{b}}$ \\
Crude fiber digestibility & $39.92 \pm 5.48^{\mathrm{c}}$ & $43.15 \pm 6.12^{\mathrm{bc}}$ & $47.38 \pm 11.02^{\mathrm{b}}$ & $60.00 \pm 1.82^{\mathrm{a}}$ & $57.06 \pm 3.87^{\mathrm{a}}$ & $54.60 \pm 6.27^{\mathrm{a}}$ \\
\hline
\end{tabular}

Note: Means with different superscript at the same rows differ significantly $(\mathrm{P}<0.05)$, tested by LSD Test. R0= Basal diet; R1= R0 + Rumensin ${ }^{\circledR} 0.3$ mg; $\mathrm{R} 2=\mathrm{R} 0$ + Syringaldehyde $0.3 \mathrm{mg} ; \mathrm{R} 3=\mathrm{R} 0$ + p-Hydroxybenzoic acid $0.3 \mathrm{mg} ; \mathrm{R} 4=\mathrm{R} 0$ + m-Hydroxybenzoic acid $0.3 \mathrm{mg} ; \mathrm{R} 5=\mathrm{R} 0+\mathrm{Oxybenzene} 0.3 \mathrm{mg}$.

Data on estimate of methane production revealed that the use of Syringaldehyde, p-Hydroxybenzoic acid, m-Hydroxybenzoic acid, and Oxybenzene significantly reduced the estimate of methane production. The exact mechanism of how these bioactive compounds affected methanogens need further study. Moreover, various attempts have been made for methane abatement through rumen microbial manipulation (Kobayashi, 2010). Some of the examples are the use of chemicals, antibiotics, and natural products such as oils, fatty acids and plant extracts. However, the use of alternative natural materials is becoming more attractive due to health concerns regarding antibiotics.

Methane is produced as a by-product of rumen metabolism and represents a loss of energy. Some related studies reported the reduction of methane by plant-derived extracts. Broudiscou et al. (2000) observed that L. officinalis (lavender) and S. virgaurea promote the extent of fermentation and that E. arvense and S. officinalis (sage) had a possible inhibitory effect on methane production in continuous culture experiment using rumen microbes. Patra et al. (2006) conducted an in vitro experiment using rumen liquor of buffalo to evaluate the the effect of five plant extracts on methanogenesis. The result showed that plant extracts of Terminlaia chebula could be used to reduce methane production.

Table 6 also demonstrates that the addition of Syringaldehyde, p-Hydroxybenzoic acid, m-Hydroxybenzoic acid, and Oxybenzene significantly reduced $(\mathrm{P}<0.05)$ the total VFA concentration. Reducing VFA concentration also occurred in Rumensin ${ }^{\circledR}$ treatment. This result was in contrary with the work of Felix et al. (2012) who reported that increasing dietary monensin did not affect ruminal VFA concentrations in vivo. Further experiment should be designed to investigate this contradiction, especially in a more dynamic fermentation system such as in continuous culture fermentation or in vivo experiment.

Data on nutrients digestibility of the in vitro fermentation are presented in Table 7. Table 7 shows that dry matter, organic matter, crude protein, and crude fiber digestibility were improved by Rumensin ${ }^{\circledR}$, Syringaldehyde, p-Hydroxybenzoic acid, m-Hydroxybenzoic acid, and Oxybenzene. This result indicated that addition of antimicrobial materials to the rumen fermentation system could improve the performance of fermentation process. These findings were in accordance to the review of Wallace et al. (2002), who stated that plant secondary compounds had great potential as 'natural' manipulators of rumen fermentation, to the potential benefit of the animal production.

In general, these experiments revealed that Syringaldehyde, p-Hydroxybenzoic acid, m-Hydroxybenzoic acid, and Oxybenzene demonstrated antimicrobial effect against the pathogenic bacteria and could slightly modify the rumen fermentation to potential benefit of host animal. Antimicrobial effect on pathogenic bacteria could be further explored to be used for controlling gastrointestinal pathogenic bacteria in ruminant, especially in newborn ruminant. Effect of these bioactive compounds on rumen fermentation still needs more intensive exploration, since these materials could acts not only as antimicrobial but also as 'rumen modifier' or 'natural' manipulator of rumen fermentation. Rochfort et al. (2008) suggested that studies on the use of plant-derived bioactive compounds should also focus on the dynamic of ruminal microflora. Moreover, regarding the use of plant-derived bioactive compounds, rumen microbiology studies are important since some species of rumen bacteria are more sensitive to certain structures than others, for example, $P$. anaerobius is extremely sensitive to both high and low molecular weight polymers (Sivakumaran et al., 2004). Additionally, many studies have relied on in vitro experiment. Therefore, further experiments should also explore more controlled in vivo research to verify the benefit of plant-derived bioactive compounds.

\section{CONCLUSION}

Purified lignin formacell from empty bunch palm fiber contained 19 phenolic compounds. Syringaldehyde, p-Hydroxybenzoic acid, m-Hydroxybenzoic acid and Oxybenzene were 4 amongst the 11 phenolic compounds isolated exhibiting the antimicrobial activity; although antimicrobial activity of all bioactive compounds was lower than that of Rumensin ${ }^{\circledR}$. The use of Syringaldehyde, p-Hydroxybenzoic acid, $\mathrm{m}$-Hydroxybenzoic acid, and Oxybenzene improved the ammonia concentration, microbial protein synthesis as well as in vitro dry matter, crude protein, and crude fiber digestibilities. However, the bioactive compounds had no effect on rumen $\mathrm{pH}$ and reduced the total volatile fatty acid concentration as well as estimate of methane production. 


\section{ACKNOWLEDGEMENT}

This work was partially supported by Directorate General of Higher Education, Republic of Indonesia and technically supported by Prof. Tati, Prof. Yandri, Ulvi, Surya, Reska, Teta, Awan, and Eka. Therefore it was a great pleasure of the authors to express their appreciation to all of them.

\section{REFERENCES}

Abrahamse, P. A., B. Vlaeminck, S. Taminga, \& J. Dijkstra. 2008. The effect of silage and concentrate type on intake behavior, rumen function, and milk production in dairy cows in early and late lactation. J. Dairy Sci. 91:4778-4792. http://dx.doi.org/10.3168/jds.2008-1350

Broudiscou. L. P., Y. Papon, \& A. F. Broudiscou. 2000. Effects of dry plant extracts on fermentation and methanogenesis in continuous culture of rumen microbes. Anim. Feed Sci. Technol. 87:263-277. http://dx.doi.org/10.1016/S03778401(00)00193-0

Conway, E. J. 1962. Ammonia. General method. In Microdiffusion analysis and volumetric error. p. 98-100. Crosby Lockwood and Son Ltd., London.

Erdemoglu, N., S. Ozkan, \& F. Tosun. 2007. Alkaloid profile and antimicrobial activity of Lupinus angustifolius L. alkaloid extract. Phytochem. Rev. 6:197-201. http://dx.doi. org/10.1007/s11101-006-9055-8

Fattouch, S., P. Caboni, V. Coroneo, C. Tuberoso, A. Angioni, S. Dessi, N. Marzouki, \& P. Cabras. 2007. Antimicrobial activity of Tunisian Quince (Cydonia oblonga Miller) pulp and peel polyphenolic extracts. J. Agric. Food Chem. 55:963-969. http://dx.doi.org/10.1021/jf062614e

Faustino, H., N. Gil, C. Baptista, \& A. P. Duarte. 2010. Antioxidant activity of lignin phenolic compounds extracted from kraft and sulphite black liquors. Molecules 15:9308-9322. http://dx.doi.org/10.3390/molecules15129308

Felix, T. L., N. A. Pyatt, \& S. C. Loerch. 2012. Effects of monensin supplementation on ruminal metabolism of feedlot cattle fed diets containing dried distillers grains. J. Anim. Sci. 90:3905-3913. http://dx.doi.org/10.2527/jas.2011-5059

Filípek, J. \& R. Dvořák. 2009. Determination of the volatile fatty acid content in the rumen liquid: Comparison of gas chromatography and capillary isotachophoresis. Acta Vet. Brno. 78:627-633. http://dx.doi:10.2754/avb2009780

Fitrial, Y., M. Astawan, S. S. Soekarto, K. G. Wiryawan, T. Wresdiyati, \& R. Khairina. 2008. Aktivitas antibakteri ekstrak biji teratai (Nymphaea pubescens Willd) terhadap bakteri patogen penyebab diare. Jurnal Teknologi dan Industri Pangan 19:158-164.

Gonzales, G. Z., R. O. Orsi, A. Fernandes, P. Rodrigues, \& S. R. C. Funari. 2006. Antibacterial activity of propolis collected in different regions of Brazil. J. Venom Anim Toxins 12:276284. http://dx.doi.org/10.1590/s1678-91992006000200009

Hamida, F., K. G. Wiryawan, \& A. Meryandini. 2015. Selection of lactic acid bacteria as probiotic candidate for chicken. Med. Pet. 38:138-144.

Hollinger, K., C. Wray, S. Evans, S. Pascoe, S. Chapell, \& Y. Jones. 1998. Salmonella typhimurium DT104 in cattle in Great Britain. J. of the American Vet. Med. Assoc. 213:1732-1733.

Johnson, J. R., M. R. Sannes, C. Croy, B. Johnston, C. Clabots, M. A. Kuskowski, J. Bender, K. E. Smith, P. L. Winokur, \& E. A. Belongia, 2007. Antimicrobial drug-resistant Escherichia coli from humans and poultry products, Minnesota and Wisconsin, 2002-2004. Emerg. Infect. Dis. 13:828-846. http://dx.doi.org/10.3201/eid1306.061576

Houser, B. A., S. C. Donaldson, R. Padte, A. A. Sawant, C. De-
bRoy, \& B. M. Jayarao. 2008. Assessment of phenotypic and genotypic diversity of Escherichia coli shed by healthy lactating dairy cattle. Foodborne Pathog. Dis. 5:41-51. http://dx.doi.org/10.1089/fpd.2007.0036

Khadem, S. \& R. J. Marles. 2010. Monocyclic phenolic acids; hydroxy- and polyhydroxybenzoic acids: Occurrence and recent bioactivity studies. Molecules 15: 7985-8005. http:// dx.doi.org/10.3390/molecules15117985

Kobayashi, Y. 2010. Abatement of methane production from ruminants: trends in the manipulation of rumen fermentation. Asian-Aust. J. Anim. Sci. 23: 410-416. http://dx.doi. org/10.5713/ajas.2010.r.01

Krehbiel, C. R., S. R. Rust, G. Zhang, \& S. E. Gilliland. 2003. Bacterial direct-feed microbial in ruminant diets: Performance response and mode of action. J. Anim. Sci. 81:E120E132.

Lee, S., A. K. Monnappa, \& R. J. Mitchell. 2012. Biological activities of lignin hydrolysate-related compounds. BMB Reports 45:265-274. http://dx.doi.org/10.5483/BMBRep.2012.45.5.265

Lehnen, R., B. Saake, \& H. H. Nimz. 2005. Impact of pulping conditions on Formacell Aspen Lignin: Investigation of methoxyl and ester groups, carbohydrates, molar mass and glass transition temperatures. Holzforschung 56:498506. http://dx.doi.org/10.1515/HF.2002.077

Lundquist, K. 1973. Formation of low molecular weight phenol from milled wood lignin during sulphate and soda cooking. Svensk Papperstidning 76:704-710.

Makkar, H. P. S., O. P. Sharma, R. K. Dawra, \& S. S. Negi. 1982. Simple determination of microbial protein in rumen liquor. J. Dairy Sci. 65:2170-2173. http://dx.doi.org/10.3168/ jds.S0022-0302(82)82477-6

Mwenya, B., C. Sar, B. Santoso, Y. Gamo, T. Kobayashi, R. Morikawa, K. Takura, K Umetsu, S. Kogawa, K. Kimura, H. Mizokoshi, \& J. Takahashi. 2005. Comparing the effects of beta 1-4-galactooligosaccharides, and L-cysteine to monensin on energy and nitrogen utilization in steers fed a very high concentrate diets. Anim. Feed Sci. Technol. 118:19-30. http://dx.doi.org/10.1016/j.anifeedsci.2004.10.014

Nazzaro, F., G. Caliendo, G. Arnesi, A. Veronesi, P. Sarzi, \& F. Fratianni. 2009. Comparative content of some bioactive compounds in two varieties of Capsicum annuum L. Sweet Pepper and evaluation of their antimicrobial and mutagenic activities. J. Food Biochem. 33:852-868. http:// dx.doi.org/10.1111/j.1745-4514.2009.00259.x

Nohynek, L. J., H. Alakomi, M. P. Kähkönen, M. Heinonen, I. K. Helander, K. Oksman-Caldentey, \& R. H. PuupponenPimiä. 2006. Berry phenolics: Antimicrobial properties and mechanisms of action against severe human pathogens. Nutrition and Cancer 54:18-32. http://dx.doi.org/10.1207/ s15327914nc5401_4

Ozturk, H., M. Pekcan, M. Sireli, \& U. R. Fidanci. 2010. Effect of propolis on in vitro rumen fermentation. Ankara Univ. Vet. Fak. Derg. 57:217-221. http://dx.doi.org/10.1501/Vetfak_0000002428

Pan, X., F. Chen, T. Wu, H. Tang, \& Z. Zhao. 2009. The acid bile tolerance and antimicrobial property of Lactobacillus acidophilus NIT. Food Control. J. 20:598-602. http://dx.doi. org/10.1016/j.foodcont.2008.08.019

Patra, A. K., D. N. Kamra, \& N. Agarwal. 2006. Effect of plant extracts on in vitro methanogenesis, enzyme activities and fermentation of feed in rumen liquor of buffalo. Anim. Feed Sci. Technol. 128:276-291. http://dx.doi.org/10.1016/j. anifeedsci.2005.11.001

Rochfort, S., A. J. Parker, \& F. R. Dunshea. 2008. Plant bioactives for ruminant health and productivity. Phytochemistry 69:299-322. http://dx.doi.org/10.1016/j.phytochem.2007.08.017

Satirapathkul, C. \& T. Leela. 2011. Growth inhibition of 
pathogenic bacteria by extract of Quercus infectoria galls. Int. J. Biosci. Biochem. Bioinform. 1:26-31. http://dx.doi. org/10.7763/IJBBB.2011.V1.5

Savoia, D. 2012. Plant-derived antimicrobial compounds: alternatives to antibiotics. Future Bicrobiol. 7:979-990. http:// dx.doi.org/10.2217/fmb.12.68

Sivakumaran, S., A. L. Molan, L. P. Meagher, B. Kolb, L. Y. Foo, G. A. Lane, G. A. Attwood, K. Fraser, \& M. Tavendale. 2004. Variation in antimicrobial action of proanthocyanidin from Dorycnium rectum against rumen bacteria. Phytochemistry 65:2485-2497. http://dx.doi.org/10.1016/j. phytochem.2004.08.046

Sticher, O. 2008. Natural product isolation. Nat. Prod. Rep. 25: 517-554. http://dx.doi.org/10.1039/b700306b

Tilley, J. M. A. \& R. A. Terry. 1963. A two stage technique for the in vitro digestion of forage. J. Br. Grassland Soc. 18:104111. http://dx.doi.org/10.1111/j.1365-2494.1963.tb00335.x

Wallace, R. J., N. R. McEwan, F. M. McIntosh, B. Teferedegne, \& C. J. Newbold. 2002. Natural products as manipulators of rumen fermentation. Asian-Aust. J. Anim. Sci. 15: 14581468.

Xia D., X. Wu, J. Shi, Q. Yang, \& Y. Zhang. 2011. Phenolic compounds from the edible seeds extract of Chinese Mei (Prunus mume Sieb. et Zucc) and their antimicrobial activity. LWT-Food Sci. Technol. 44:347-349. http://dx.doi. org/10.1016/j.lwt.2010.05.017

Yang, H., R. Yan, H. Chen, D. H. Lee, \& C. Zheng. 2007. Characteristics of hemicellulose, cellulose and lignin pyrolysis. Fuel 86:1781-1788. http://dx.doi.org/10.1016/j. fuel.2006.12.013 